\title{
ANALISIS PERANCANGAN SISTEM INFORMASI PUSAT STUDI PADA FAKULTAS ILMU KOMPUTER UNIVERSITAS ESA UNGGUL
}

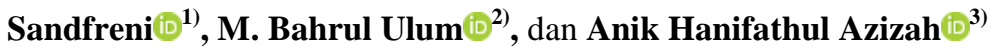 \\ ${ }^{1,3}$ Sistem Informasi, Universitas Esa Unggul \\ ${ }^{2}$ Teknik Informatika, Universitas Esa Unggul \\ 1,2,3 Jalan Arjuna Utara No. 9 Kebon Jeruk Jakarta Barat 11540 \\ E-mail : sandfreni@esaunggul.ac.id ${ }^{1)}$, m.bahrul_ulum@esaunggul.ac.id ${ }^{2)}$, anik.hanifa@esaunggul.ac.id ${ }^{3)}$
}

\begin{abstract}
ABSTRAK
Dosen adalah salah satu komponen esensial dalam suatu system pendidikan di perguruan tinggi. Tugas utama dosen tidak hanya mengajar dan membimbing mahasiswa saja tetapi juga melaksanakan kegiatan penelitian dan pengabdian masyarakat yang termasuk ke dalam tridharma perguruan tinggi. Semenjak pandemi covid 19 work from home sudah tidak asing lagi di masyarakat. Di Universitas pun sudah memasuki tahun kedua kuliah daring melalui e-Learning kampus masing-masing, tetapi e-Learning kampus hanya mengakomodir kegiatan belajar mengajar tidak mencakup seluruh tridharma dosen. Maka dari itu diperlukan suatu sistem yang dapat mengakomodir kegiatan pusat studi, yaitu Penelitian, Pengabdian Masyarakat, Publikasi Jurnal, Seminar, dan Pelatihan. Pusat studi adalah Kelompok keilmuan dan kepakaran yang mempunyai minat terhadap kajian ilmu yang melakukan kegiatan perencanaan dan pelaksanaan, pengendalian mutu kegiatan serta kerja sama riset dan pengabdian kepada masyarakat, dalam rangka pengembangan keilmuan yang bersifat mono disiplin dan atau multidisiplin sebagai penunjang pelaksanaan tugas fakultas. Maka dari itu fakultas memerlukan suatu sistem informasi pusat studi yang dapat mengorganisir kegiatan di pusat studi sehingga memudahkan pelaporan kegiatan dosen terhadap pimpinan fakultas dan repository online atau media penyimpanan online untuk proposal dan laporan, serta surat tugas yang di verifikasi oleh Dekan dan Kepala Pusat Studi di Fakultas Ilmu Komputer UEU (Fasilkom UEU), yang mana data tersebut bisa digunakan lagi pada tingkat universitas.
\end{abstract}

Kata Kunci: Tridharma Dosen, Penelitian, Pengabdian Masyarakat, Pusat Studi, Sistem Informasi.

\section{PENDAHULUAN}

Perkembangan teknologi informasi menjadi peran penting dalam segala jenis kegiatan. Baik individu maupun organisasi, pada era ini mengandalkan teknologi pada setiap aktivitas guna meningkatkan efektifitas dan efisiensi hasil yang dicapai. Salah satu organisasi yang mengandalkan Teknologi adalah dunia pendidikan yaitu universitas (Lestari, 2018) . Tidak hanya sebagai sarana dalam belajar mengajar tetapi dalam mendukung kegiatan tri dharma dosen selain belajar mengajar yaitu pengabdian kepada masyarakat, penelitian serta kegiatan pelatihan dan seminar. Perencanaan Strategi IT merupakan langkah pertama antara proses dari sebuah sistem informasi perusahaan dan merupakan pedoman dari system informasi perusahaan serta dasar pelaksanaan (Sandfreni \& Adikara, 2019).

Di dunia pendidikan khususnya perguruan tinggi, keberadaan dosen merupakan salah satu faktor yang dianggap mutlak adanya, Dosen adalah salah satu komponen esensial dalam suatu sistem pendidikan di perguruan tinggi. Peran, tugas, dan tanggungjawab dosen sangat penting dalam mewujudkan tujuan pendidikan nasional, untuk melaksanakan fungsi, peran, dan kedudukan yang sangat strategis tersebut, diperlukan dosen yang profesional. Sebagaimana diamanatkan dalam UU Nomor 14 Tahun 2005 tentang Guru dan Dosen, dosen dinyatakan sebagai pendidik profesional dan ilmuwan dengan tugas utama mentransformasikan, mengembangkan, dan menyebarluaskan ilmu pengetahuan, teknologi, dan seni melalui pendidikan, penelitian, dan pengabdian kepada masyarakat (Bab 1 Pasal 1 ayat 2)(Sunarto, 2015).

Pandemi Covid-19 membuat semua kegiatan yang dilakukan di luar rumah menjadi online seperti sekolah, kuliah, dan lain-lain, maka dari itu kita membutuhkan sarana Sistem informasi. Sistem Informasi adalah suatu system di dalam suatu organisasi yang mempertemukan kebutuhan pengelolaan transaksi harian, mendukung operasi, bersifat manajerial, dan kegiatan strategi dari suatu organisasi dan menyediakan pihak luar tertentu dengan laporan-laporan yang dibutuhkan.(Hutahaean, 2017).

Sistem informasi juga merupakan suatu sistem dalam suatu organisasi yang merupakan kombinasi dari orangorang, fasilitas, teknologi, media dan pengendalian yang ditujukan untuk mendapatkan jalur komunikasi penting, memproses tipe transaksi rutin tertentu, memberi sinyal kepada manajemen dan yang lainnya terhadap kejadiankejadian internal dan eksternal yang penting serta menyediakan suatu dasar informasi untuk pengambilan keputusan yang tepat.(Elisabet Yunaeti Anggraeni, 2017)

Universitas Esa Unggul merupakan salah satu perguruan tinggi swasta di Jakarta Barat, memiliki sepuluh Fakultas Program Sarjana dan empat Program Pascasarjana. Universitas Esa Unggul sudah memakai suatu Sistem Informasi untuk kegiatan belajar 
mengajarnya yaitu Siakad. Siakad adalah suatu system informasi yang membantu dosen dalam kegiatan belajar mengajar serta perwalian dan pembimbingan tugas akhir dan kerja praktik. Tetapi sistem yang sudah ada sekarang belum melibatkan kegiatan penelitian, pengabdian masyarakat, pelatihan dan publikasi/seminar yang merupakan bagian dari Tridharma perguruan tinggi.

Dosen Universitas Esa Unggul saat ini ketika mengajukan proposal dan melakukan pelaporan kegiatan atau pengajuan untuk kegiatan seminar, pelatihan, dan penelitian, sifatnya masih manual. Untuk mempermudah dosen dalam perihal pengajuan dan pelaporan setiap kegiatan yang akan diadakan oleh dosen, alangkah baiknya dikerjakan dengan bantuan software/sistem informasi agar mampu mengefektifkan waktu dan juga bisa dilakukan dengan jarak jauh, maka dari itu penulis ingin meneliti dan merancang sebuah Sistem Informasi Pusat Studi Fakultas Ilmu Komputer. Sistem ini nantinya akan digunakan untuk layanan sistem informasi bagi seluruh dosen Fakultas Ilmu Komputer Universitas Esa Unggul yang mencerminkan, data dan pengajuan serta pelaporan penelitian, pengabdian masyarakat, publikasi/seminar, dan pelatihan.

Dalam proses pengembangan sistem informasi, terdapat tahap penting yaitu Rekayasa Kebutuhan (Requirement Engineering) yang merupakan langkah awal dalam sebuah proses pengembangan sistem informasi yang perlu dilakukan untuk mendapatkan sebuah sistem informasi yang baik dan berkualitas (Sandfreni,Surendro, 2016) Rekayasa Kebutuhan dapat mempengaruhi hasil dari pengembangan suatu sistem informasi karena merupakan proses untuk merumuskan kebutuhan pengguna sistem, dengan cara mengidentifikasi stakeholder serta kebutuhan mereka, selanjutnya mendokumentasikan nya ke dalam format yang memudahkan untuk di analisis, mengomunikasikan nya dan meneruskan pengembangan sistem.

Dalam hal ini peneliti akan menganalisis terlebih dahulu proses bisnis yang sedang berjalan di Pusat Studi Fakultas Ilmu Komputer UEU baik dari segi system maupun dari segi user yang terlibat dalam proses tersebut. Serta melakukan analisis kebutuhan dari stakeholder yang terlibat dan lingkungan yang ada (Software \& Hardware). Setelah hasil analisis proses bisnis dibuat maka dilanjutkan dalam proses rekayasa kebutuhan dan akan diterjemahkan dalam diagram Unified Modelling Language (UML). UML merupakan alat perancangan sistem yang berorientasi pada objek. UML menyediakan banyak sekali diagram yang diperlukan untuk menjelaskan sistem yang sedang dikembangkan, baik dari aspek statis maupun dinamis nya. (OMG, 2021)

Secara filosofi kemunculan UML diilhami oleh konsep yang telah ada yaitu konsep pemodelan Object Oriented (OO), karena konsep ini menganalogikan sistem seperti kehidupan nyata yang didominasi oleh objek dan digambarkan atau di notasi dalam simbolsimbol yang cukup spesifik maka OO memiliki proses standar dan bersifat independent. UML (Unified Modelling Language) adalah salah satu alat bantu yang sangat andal di dunia pengembangan sistem berorientasi objek. Hal ini disebabkan karena UML menyediakan bahasa pemodelan visual yang memungkinkan bagi pengembang sistem untuk membuat cetak biru atas visi mereka dalam bentuk yang baku, mudah dimengerti serta dilengkapi dengan mekanisme yang efektif untuk berbagi (sharing) dan mengomunikasikan rancangan mereka dengan yang lain. (Munawar, 2018).

Penerjemahan kedalam diagram UML dapat membantu melihat definisi hasil dari proses rekayasa kebutuhan dalam berbagai perspektif (Adikara \& Sandfreni, 2020), sehingga dapat membantu proses pengembangan sistem informasi pusat studi.

\section{RUANG LINGKUP}

Pada sebuah universitas, ada beberapa kegiatan yang dilakukan karena adanya manajemen pusat studi, yaitu Penelitian, Pengabdian Masyarakat, Publikasi Jurnal, Seminar, dan Pelatihan. Pusat studi adalah Kelompok keilmuan dan kepakaran yang mempunyai minat terhadap kajian ilmu yang melakukan kegiatan perencanaan dan pelaksanaan, pengendalian mutu kegiatan serta kerja sama riset dan pengabdian kepada masyarakat, dalam rangka pengembangan keilmuan yang bersifat mono disiplin dan atau multidisiplin sebagai penunjang pelaksanaan tugas fakultas

1. Adapun identifikasi masalah yang akan dibahas yaitu:

1) Bagaimana merancang sebuah sistem yang dapat mengakomodir program Pengabdian Masyarakat, Penelitian, Publikasi dan Seminar.

2) Belum adanya repository online atau media penyimpanan online untuk proposal, dan surat tugas yang di verifikasi oleh Dekan dan Kepala Pusat Studi (Kapusdi) di Fakultas Ilmu Komputer UEU.

3) UEU khususnya Fakultas Ilmu Komputer saat ini belum ada sistem yang dapat membantu dosen dalam membuat laporan atau pengajuan kegiatan seminar, pengabdian masyarakat dan penelitian.

2. Batasan Permasalahan

1) Membuat design perancangan sistem informasi pusat studi di Fakultas Ilmu Komputer UEU yang dapat membantu kegiatan Litabdimas Dosen.

2) Sistem Informasi tersebut meliputi program Pengabdian Masyarakat, Penelitian, Publikasi dan Seminar.

3. Rencana hasil yang didapatkan.

1) Memberikan hasil rancangan sistem yang mudah dipahami dan di terjemahkan dalam pembuatan sistem informasi.

\section{BAHAN DAN METODE}

Sistem informasi pusat studi merupakan suatu sistem administratif yang dapat membantu fakultas mendata 
para Dosen dalam pelaporan kegiatan litabdimas, pelatihan dan seminar yang akan dilakukan. Dan tentunya memberikan kemudahan kepada Dosen, Dekan dan Kepala Pusat Studi dalam melakukan koordinasi kegiatan dan dapat menyimpan semua dokumentasi sehingga dapat memudahkan pencarian data tersebut.

Pada Tabel 1. Analisis Kebutuhan User menjelaskan secara rinci kebutuhan dari setiap user. Pada penelitian ini dilakukan dengan melakukan wawancara secara internal dengan Dosen, Kepala Pusat Studi dan Dekan. Dari hasil wawancara tersebut dapat disimpulkan ada tiga aktor yang terlibat dalam sistem yaitu Dosen, Kepala Pusat Studi dan Dekan.

Tabel 1. Analisis Kebutuhan User

\begin{tabular}{|l|l|}
\hline User & Kemampuan dalam Sistem \\
\hline Dosen & 1.Mengakses Sistem \\
& $\begin{array}{l}\text { 2.Mengajukan proposal dan laporan } \\
\text { Penelitian, Pengabdian Masyarakat, } \\
\text { Pelatihan dan Seminar. } \\
\text { 3.Melihat Notifikasi Pengajuan yang sudah } \\
\text { disetujui oleh Kepala Pusat Studi dan } \\
\text { Dekan. }\end{array}$ \\
\hline Dekan & $\begin{array}{l}\text { 1.Mengakses Sistem } \\
\text { 2.Memeriksa dan memverifikasi pengajuan } \\
\text { proposal dan laporan Penelitian, }\end{array}$ \\
& $\begin{array}{l}\text { Pengabdian Masyarakat, Pelatihan dan } \\
\text { Seminar dari Dosen yang sudah diperiksa } \\
\text { dan di verifikasi oleh Kepala Pusat Studi. }\end{array}$ \\
& $\begin{array}{l}\text { 3.Melihat notifikasi pengajuan dari Kepala } \\
\text { Pusat Studi. }\end{array}$ \\
\hline Kepala Pusat & 1.Mengakses Sistem \\
Studi & 2.Memeriksa dan memverifikasi proposal \\
& dan laporan Penelitian, Pengabdian \\
& $\begin{array}{l}\text { Masyarakat, Pelatihan dan Seminar yang } \\
\text { diajukan oleh Dosen. } \\
\text { 3.Melihat notifikasi pengajuan dari Dosen }\end{array}$ \\
\hline
\end{tabular}

Selanjutnya dilakukan analisis kebutuhan Fungsional dan Non Fungsional dimana analisis ini dilakukan untuk mengetahui spesifikasi dan kondisi yang baik untuk sistem dengan mempertimbangkan semua kebutuhan dari sistem.

Kebutuhan Fungsional:

1. Sistem dapat melakukan Login untuk melakukan pengelolaan data.

2. Sistem dapat melakukan penyimpanan data.

Kebutuhan Non Fungsional:

1. Sistem dapat dijalankan di semua browser.

2. Tampilan antar muka aplikasi sangat mudah dipahami.

3. Aplikasi web responsif di berbagai device.

4. Respons time saat aplikasi dibuka tidak lebih dari 15 detik

\subsection{Sistem Informasi}

Sistem informasi adalah cara-cara organisasi untuk mengumpulkan, memasukkan, mengolah, dan menyimpan data, yang terdiri dari empat komponen perangkat lunak (software), perangkat keras (hardware), infrastruktur, dan Sumber Daya Manusia (SDM). Sehingga sebuah organisasi dapat mencapai tujuan yang telah ditetapkan.(Triandini dkk., 2019)

Sistem informasi sesungguhnya adalah sebuah sub sistem yang merupakan bagian dari sebuah sistem lain yang lebih besar. Sistem informasi tidak dapat dirancang dan dioperasikan secara terpisah dari sub sistem yang lain. Sistem informasi hanya satu dari beberapa sub sistem yang dimiliki oleh sebuah organisasi. Fungsi dari sub sistem yang lain tergantung sepenuhnya kepada peranan organisasi. Sub sistem-sub sistem tersebut biasanya diuraikan dalam aktivitas-aktivitas dan sesuai dengan departemen tertentu dari suatu organisasi (Lipursari, 2019). Maka dari itu, dapat disimpulkan bahwa sistem informasi adalah suatu sistem yang menyediakan informasi untuk manajemen dalam mengambil keputusan dan juga untuk menjalankan operasional perusahaan, di mana sistem tersebut merupakan kombinasi dari orang-orang, teknologi informasi dan prosedur-prosedur yang tergorganisasi.

\subsection{Unified Modelling Language (UML)}

Unified Modeling Language (UML) adalah sebuah bahasa yang berdasarkan grafik atau gambar untuk memvisualisasikan, spesifikasi, membangun, dan pendokumentasian dari sebuah sistem pengembangan software berbasis OO (Object-Oriented). UML sendiri juga memberikan standar penulisan sebuah sistem blue print, yang meliputi konsep bisnis proses, penulisan kelaskelas dalam bahasa program yang spesifik, skema database, dan komponen-komponen yang diperlukan dalam sistem software (Irmayani \& Susyatih, 2017).

Maka dari itu, dapat disimpulkan bahwa UML atau "Unified Modelling Language" adalah suatu metode pemodelan secara visual yang berfungsi sebagai sarana perancangan sistem berorientasi objek. Banyaknya jenisjenis UML memiliki karakteristiknya tersendiri, yang dapat digunakan sesuai dengan kegunaannya.

Unified Modeling Language (UML) adalah bahasa spesifikasi standar yang dipergunakan untuk mendokumentasikan, spesifikasi dan membangun perangkat lunak. UML merupakan metodologi dalam mengembangkan sistem berorientasi objek seperti alat untuk mendukung suatu sistem yang menyediakan informasi untuk manajemen dalam mengambil keputusan dan juga untuk menjalankan operasional perusahaan, di mana sistem tersebut merupakan kombinasi dari orangorang, teknologi informasi dan prosedur-prosedur yang tergorganisasi.

\subsubsection{Use Case Diagram}

Use Case atau diagram Use Case merupakan pemodelan untuk kelakuan (behaviour) sistem informasi yang akan dibuat. Use Case mendeskripsikan sebuah interaksi antara satu atau lebih aktor dari dengan sistem informasi yang akan dibuat (Hendini, 2016). Jadi dapat di katakan bahwa Use Case adalah suatu urutan interaksi yang saling berkaitan antara sistem dan aktor. Use case 
dijalankan melalui interaksi antara user nya dengan cara menggambarkan tipe dari interaksi user dalam suatu program.

\subsubsection{Sequence Diagram}

Sequence Diagram menggambarkan bagaimana sistem merespons kegiatan user. Sequence Diagram yang dibuat yaitu yang berhubungan langsung dengan kegiatan utama dari sistem informasi anggaran pendapatan dan belanja desa berbasis objek (Irmayani \& Susyatih, 2017). Diagram sequence menggambarkan kelakuan objek pada use case dengan mendeskripsikan waktu hidup objek dan message yang dikirimkan dan diterima antar objek. Oleh karena itu untuk menggambarkan diagram sequence maka harus diketahui objek-objek yang terlibat dalam sebuah use case beserta metode-metode yang dimiliki kelas yang di instansi menjadi objek itu (Sukamto \& Shalahuddin, 2016). Membuat diagram sequence juga dibutuhkan untuk melihat skenario yang ada pada use case. Jadi, dari penjabaran diatas dapat disimpulkan bahwa Sequence Diagram menggambarkan kelakuan objek pada use case dengan mendeskripsikan waktu hidup objek yang terlibat dalam sebuah use case beserta metode- metode yang dimiliki kelas yang di instansi menjadi objek itu. Membuat diagram sequence juga dibutuhkan untuk melihat skenario yang ada pada use case.

\subsubsection{Activity Diagram}

Activity Diagram (diagram aktivitas) menggambarkan berbagai alur aktivitas dalam sistem yang sedang dirancang, bagaimana masing-masing alir berawal, decision yang mungkin terjadi, menggambarkan proses paralel yang mungkin terjadi pada beberapa eksekusi dan bagaimana mereka berakhir (Hendini, 2016). Jadi dapat di katakan bahwa Activity diagram adalah sesuatu yang menjelaskan tentang alir kegiatan dalam program yang sedang dirancang, bagaimana proses berawal, keputusan yang mungkin terjadi, dan bagaimana sistem tersebut akan berakhir.

\subsubsection{Class Diagram}

Class diagram adalah merupakan hubungan antar kelas dan penjelasan detail tiap-tiap kelas di dalam model desain dari suatu sistem, juga memperlihatkan aturanaturan dan tanggung jawab entitas yang menentukan perilaku sistem (Hendini, 2016). Jadi dapat di katakan bahwa Class diagram adalah visual dari struktur sistem program pada jenis-jenis yang di bentuk. Class diagram merupakan alur jalannya sebuah database pada system yang akan dibangun atau dibuat.

\section{PEMBAHASAN}

Pada bagian pembahasan akan dijelaskan proses bisnis yang sudah ada dan usulan dari proses bisnis yang akan dirancang dari hasil analisis kebutuhan (Sandfreni,Adikara dkk, 2018) yang dijelaskan dan digambarkan menggunakan UML secara terinci.

\subsection{Proses Bisnis Yang Sedang Berjalan}

Proses bisnis yang saat ini terjadi dapat dilihat pada Gambar 1. Proses Bisnis yang Sedang Berjalan. Pada gambar tersebut menjelaskan bahwa setiap Dosen harus mengajukan kegiatan yang akan dilakukan oleh Dosen. Setelah menentukan kegiatan yang akan dilakukan Dosen harus mengunggah proposal dimana proposal tersebut sudah sesuai dengan standar tulisan yang dibuat oleh LPPM. Kepala Pusat Studi adalah pihak pertama yang akan memverifikasi dan menyetujui proposal, setelah Kepala Pusat Studi memverifikasi dan menyetujui proposal, kemudian proposal akan dicek kembali oleh Dekan untuk di verifikasi dan disetujui. Jika proposal sudah disetujui, maka akan dibuat Surat Tugas untuk melakukan kegiatan, dan jika kegiatan sudah selesai maka akan dikeluarkan Surat Keterangan Selesai melaksanakan kegiatan.

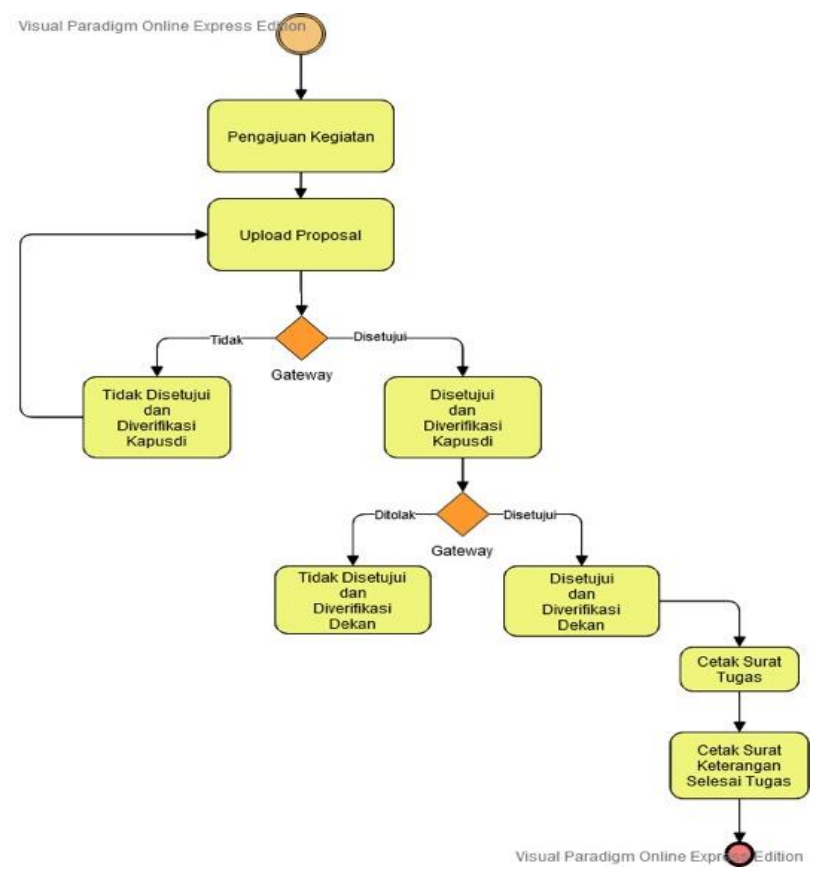

Gambar 1. Proses Bisnis yang Sedang Berjalan

\subsection{Proses Bisnis Usulan}

Pemodelan proses bisnis adalah teknik atau cara untuk memahami, mendesain dan menganalisa suatu proses bisnis, dimana manfaatnya untuk membantu institusi/perusahaan memahami proses bisnisnya dengan baik, mengidentifikasi permasalahan seperti critical path atau bottleneck yang mungkin terjadi, mengembangkan, mendokumentasikan serta mengomunikasikan nya pada semua pemangku kepentingan bisnis. Sehingga perusahaan dapat meningkatkan performance dari pengelolaan proses bisnisnya. (Ismanto dkk., 2020)

Proses bisnis yang diusulkan dapat dilihat pada Gambar 2. Proses Bisnis Usulan. Pada rencana usulan rancangan system, Dosen, Dekan dan Kapusdi dapat melakukan login untuk mengakses sistem tersebut sesuai 
dengan role masing-masing. Dosen yang akan melakukan kegiatan seperti penelitian, pengabdian masyarakat, pelatihan dan publikasi/seminar dapat mengunggah proposal kegiatan, kemudian akan di verifikasi dan disetujui menggunakan sistem. Jika tidak disetujui, maka dosen akan melakukan revisi proposal sesuai dengan kesalahan yang ada, jika disetujui maka akan terbit surat tugas untuk melakukan kegiatan. Setelah itu, dosen akan mengunggah hasil kegiatan yang sudah dilakukan. Kemudian akan diterbitkan surat keterangan telah selesai melakukan kegiatan.

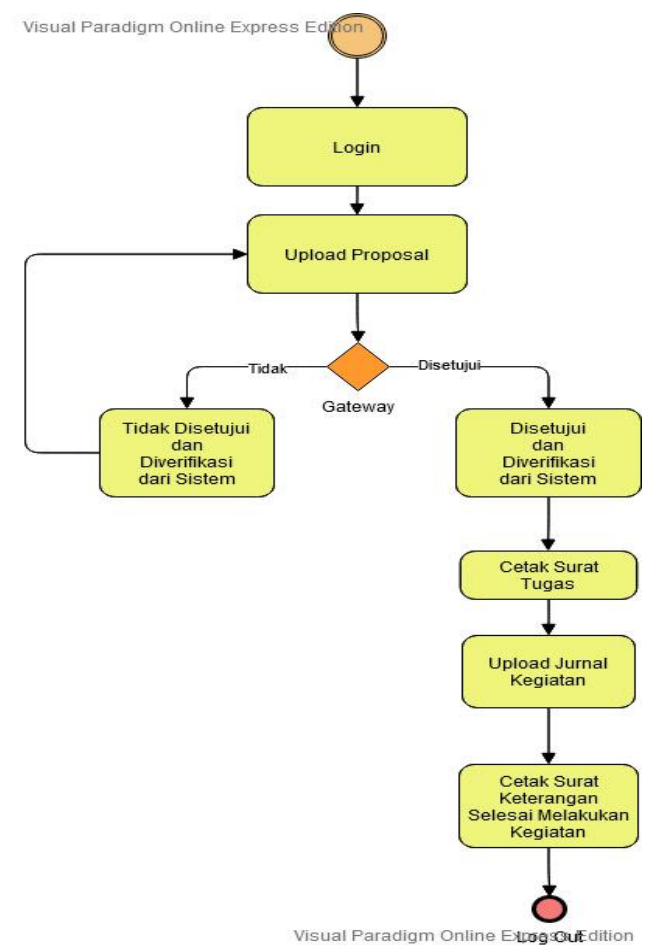

Gambar 2. Proses Bisnis Usulan

\subsection{Perancangan Usulan}

Rancangan usulan Pengembangan Sistem Informasi Pusat Studi menggunakan empat diagram, yaitu Activity Diagram, Use case Diagram, Sequence Diagram dan Class Diagram.

\subsubsection{Activity Diagram}

Activity Diagram merupakan rancangan aliran aktivitas atau aliran kerja dalam sebuah sistem yang akan dijalankan. Activity Diagram juga digunakan untuk mendefinisikan atau mengelompokkan aluran tampilan dari sistem tersebut. Activity Diagram memiliki komponen dengan bentuk tertentu yang dihubungkan dengan tanda panah. Panah tersebut mengarah ke urutan aktivitas yang terjadi dari awal hingga akhir. (Rizky Muhammad; Irma Kartika Wairooy, S.Kom., 2019)

1. Activity Diagram Penelitian

Pada activity diagram penelitian terdapat tiga aktor yaitu Dosen, Kapusdi dan Dekan. Pada Gambar
3. Activity Diagram Penelitian dijelaskan tahapan bahwa Dosen melakukan pendaftaran penelitian dan harus upload proposal yang mana proposal tersebut harus di verifikasi oleh Kapusdi terlebih dahulu baru di verifikasi oleh Dekan. Setelah di verifikasi dan disetujui maka Dosen tersebut mendapatkan surat tugas untuk melakukan penelitian dan melanjutkan kegiatan penelitian dan melaporkan kegiatan penelitian berbentuk laporan penelitian pada gambar 3.

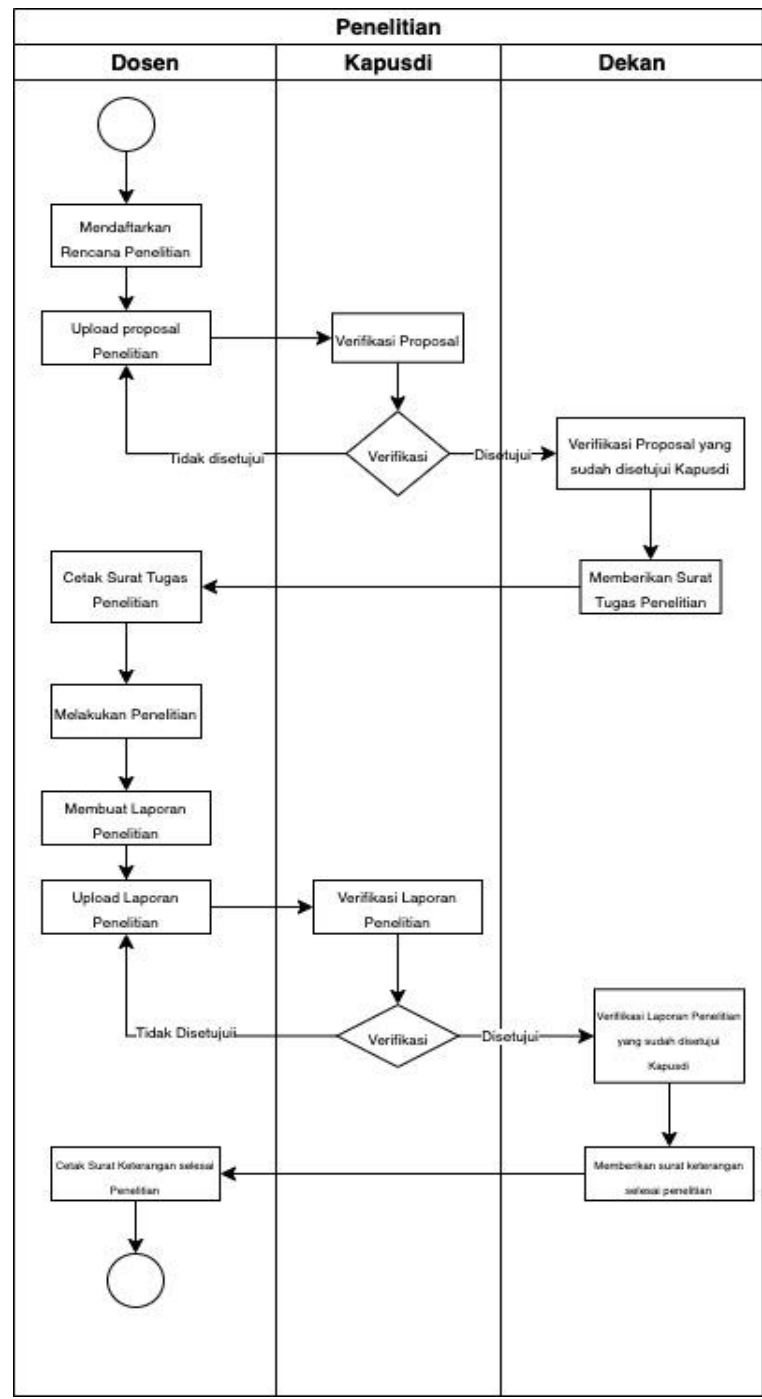

Gambar 3. Activity Diagram Penelitian

\section{Activity Diagram Pengabdian Masyarakat}

Pada activity diagram pengabdian masyarakat terdapat tiga aktor yaitu Dosen, Kapusdi dan Dekan. Pada Gambar 4. Activity Diagram Pengabdian Masyarakat dijelaskan tahapan bahwa Dosen mendaftarkan rencana kegiatan pengabdian masyarakat dan harus upload proposal yang mana proposal tersebut harus di verifikasi oleh Kapusdi terlebih dahulu baru di verifikasi oleh Dekan. Setelah di verifikasi dan disetujui maka Dosen tersebut 
mendapatkan surat tugas untuk melakukan penelitian dan melanjutkan kegiatan pengabdian masyarakat dan melaporkan kegiatan pengabdian masyarakat berbentuk laporan pengabdian masyarakat.

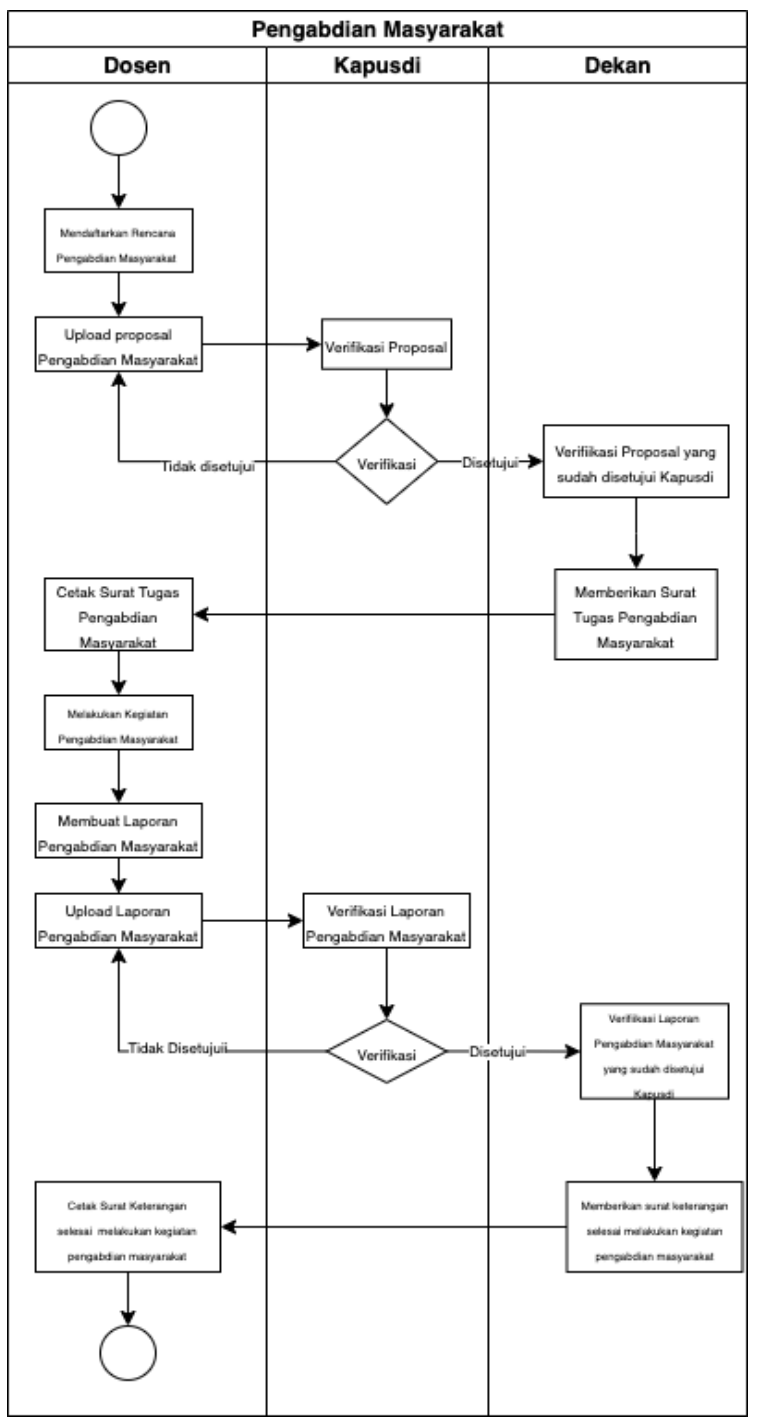

Gambar 4. Activity Diagram Pengabdian Masyarakat

3. Activity Diagram Pelatihan

Pada activity diagram pelatihan terdapat tiga aktor yaitu Dosen, Kapusdi dan Dekan. Pada

Gambar 5. Activity Diagram Pelatihan dijelaskan tahapan bahwa Dosen mendaftarkan rencana kegiatan pelatihan/training dan upload undangan pelatihan/brosur pelatihan yang mana akan diperiksa dan di verifikasi oleh Kapusdi terlebih dahulu baru di verifikasi oleh Dekan. Setelah di verifikasi dan disetujui maka Dosen tersebut mendapatkan surat tugas untuk melakukan pelatihan/training dan melaporkan kegiatan pelatihan/ training berbentuk laporan.

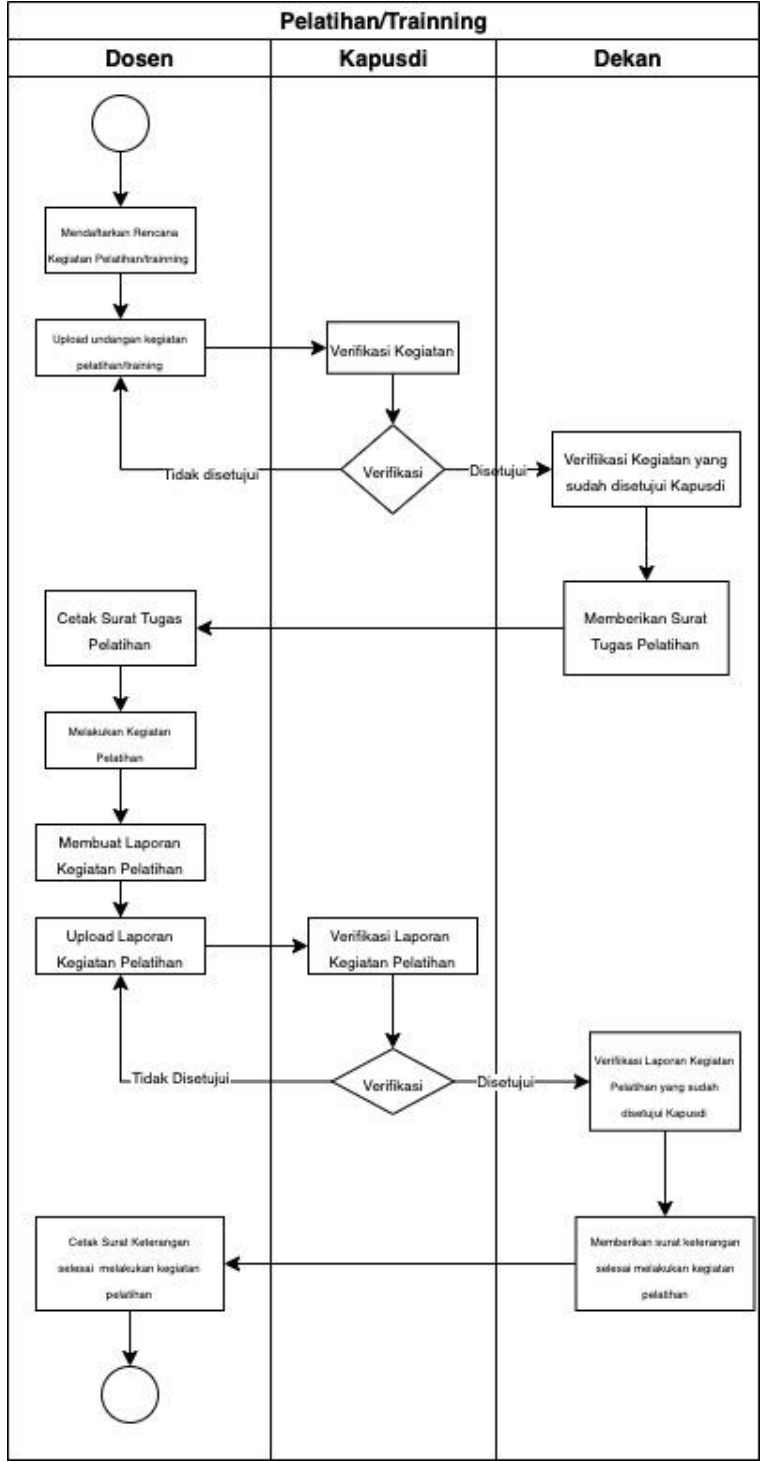

Gambar 5. Activity Diagram Pelatihan

4. Activity Diagram Publikasi/Seminar

Pada activity diagram publikasi/seminar terdapat tiga aktor yaitu Dosen, Kapusdi dan Dekan. Pada Gambar 6. Activity Diagram Publikasi/Seminar dijelaskan tahapan bahwa Dosen mendaftarkan rencana kegiatan publikasi/seminar dan upload undangan publikasi/seminar yang mana akan diperiksa dan di verifikasi oleh Kapusdi terlebih dahulu baru di verifikasi oleh Dekan. Setelah di verifikasi dan disetujui maka Dosen tersebut mendapatkan surat tugas untuk melakukan kegiatan publikasi/seminar dan melaporkan kegiatan publikasi/seminar berbentuk laporan. 


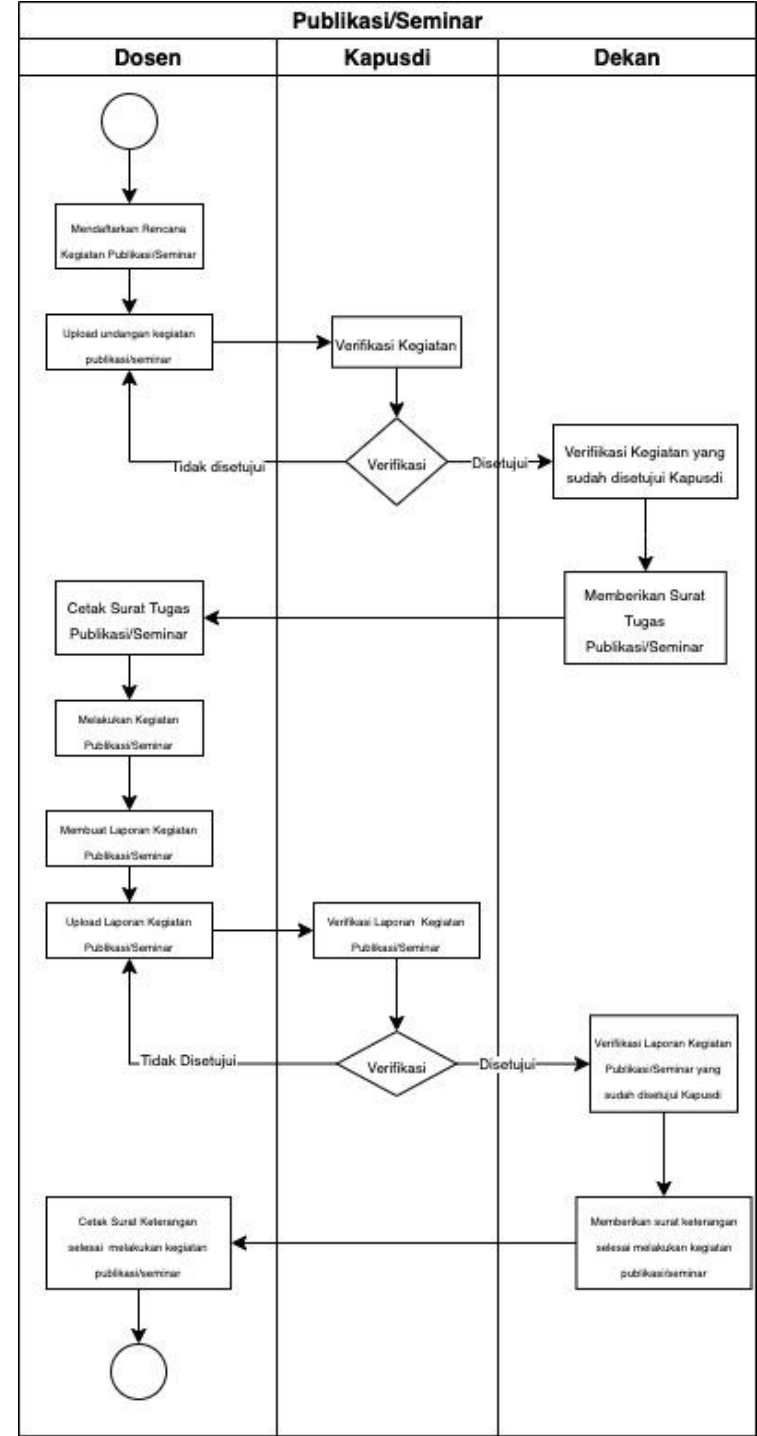

Gambar 6. Activity Diagram Publikasi/Seminar

\subsubsection{Use Case Diagram}

Diagram use case menyajikan interaksi antara use case dan aktor. Dimana aktor dapat berupa orang, peralatan atau sistem lain yang berinteraksi dengan sistem yang sedang dibangun. Use case menggambarkan fungsionalitas sistem atau persyaratan yang harus dipenuhi sistem dari pandangan.(Setiawan \& Khairuzzaman, 2017).

1. Use Case Diagram Penelitian

Pada use case diagram penelitian sama hal nya dengan activity diagram dimana Dosen, Kapusdi dan Dekan bisa melakukan login di sistem tersebut dengan role masing-masing actor sesuai dengan panah atau garis yang digambarkan pada Gambar 7. Use Case Diagram Penelitian.

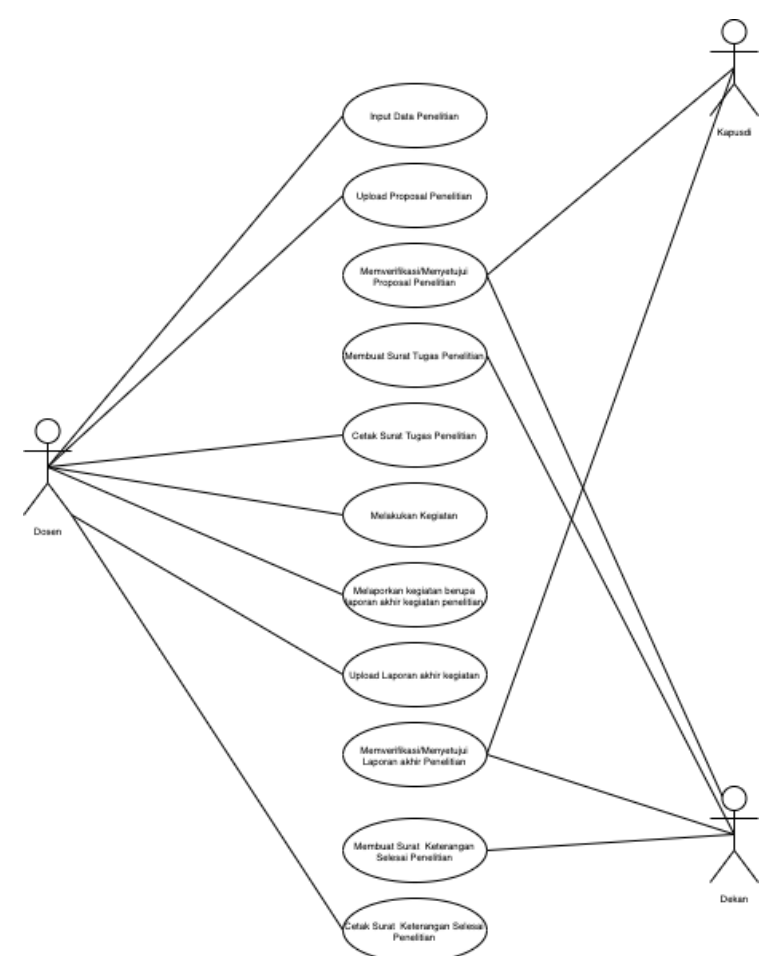

Gambar 7. Use Case Diagram Penelitian

2. Use Case Diagram Pengabdian Masyarakat

Pada use case diagram pengabdian masyarakat sama hal nya dengan activity diagram dimana Dosen, Kapusdi dan Dekan bisa melakukan login di sistem tersebut dengan role masing-masing actor sesuai dengan panah atau garis yang digambarkan pada Gambar 8 .

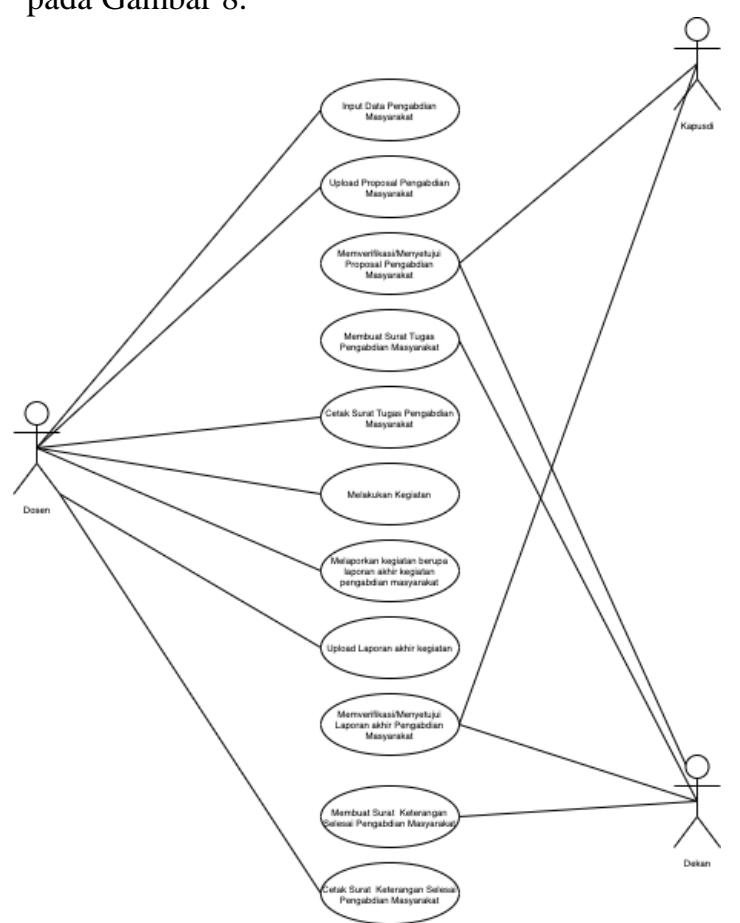

Gambar 8. Use Case Diagram Pengabdian Masyarakat 
3. Use Case Diagram Pelatihan

Pada use case diagram pelatihan/trainning sama hal nya dengan activity diagram dimana Dosen, Kapusdi dan Dekan bisa melakukan login disistem tersebut dengan role masing-masing actor sesuai dengan panah atau garis yang digambarkan pada Gambar 9 .

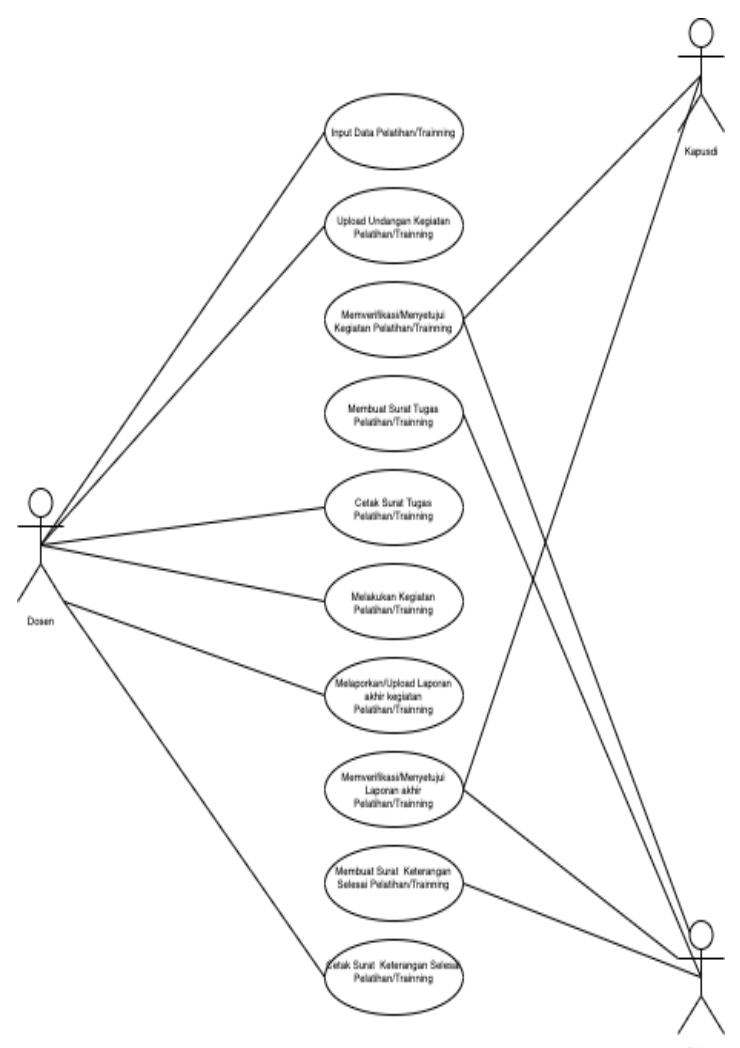

Gambar 9. Use Case Diagram Pelatihan

4) Use Case Diagram Publikasi/Seminar

Pada use case diagram publikasi/seminar sama hal nya dengan activity diagram dimana Dosen, Kapusdi dan Dekan bisa melakukan login disistem tersebut dengan role masing-masing actor sesuai dengan panah atau garis yang digambarkan pada Gambar 10 .

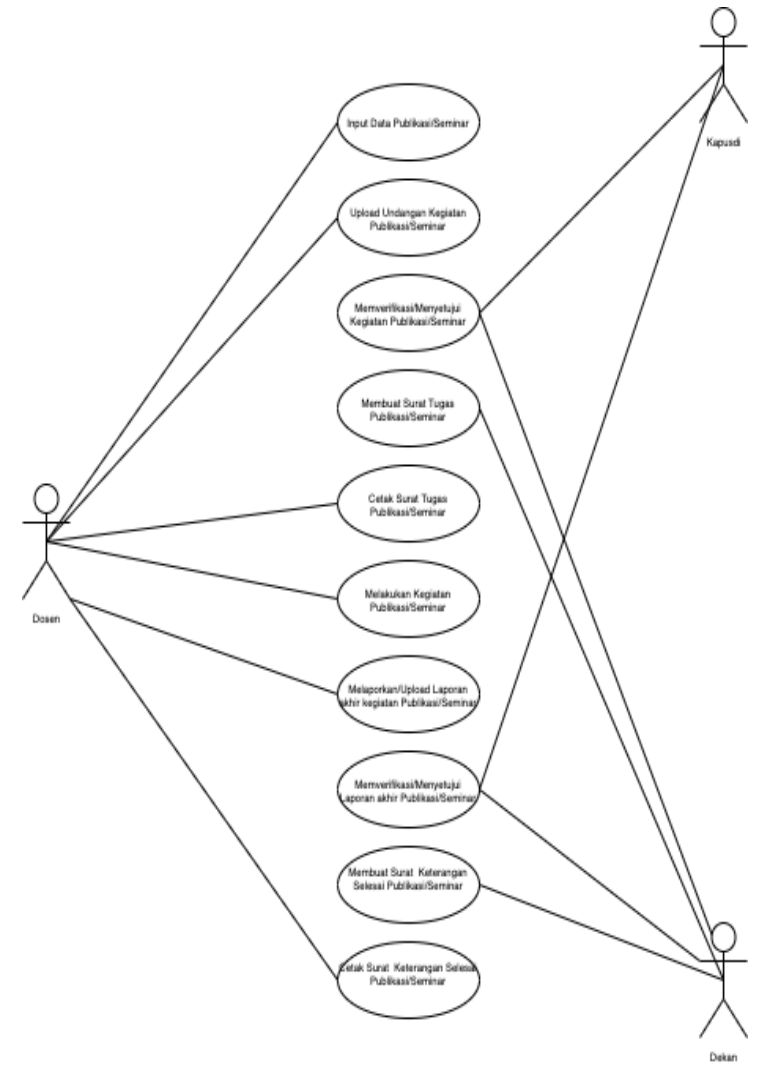

Gambar 10. Use Case Diagram Publikasi/Seminar

\subsubsection{Sequence Diagram}

Sequence Diagram adalah diagram yang menjelaskan interaksi objek diantara objek-objek tersebut yang digunakan guna menjelaskan perilaku scenario dari entitas dan sistem yang berinteraksi. Sequence Diagram berhubungan erat dengan Use Case Diagram, berasio 1:1.(Alvin dkk, 2021) Tujuan dari Sequence Digram adalah:

1. Menghubungkan requirement agar lebih mudah dielaborasi menjadi model design.

2. Merupakan diagram yang relevan menguraikan model deskripsi use case ke bentuk spesifikasi design.

3. Analisis dan Desain, sebagai identifikasi metode sebuah sistem.

4. Dapat memodelkan Use Case.

5. Berfungsi memodelkan logika.

6. Berfungsi memodelkan logika dari service.

Pada Gambar 11, menjelaskan interaksi objek antara objek dan actor di perancangan sistem informasi pusat studi yang akan dibuat. 


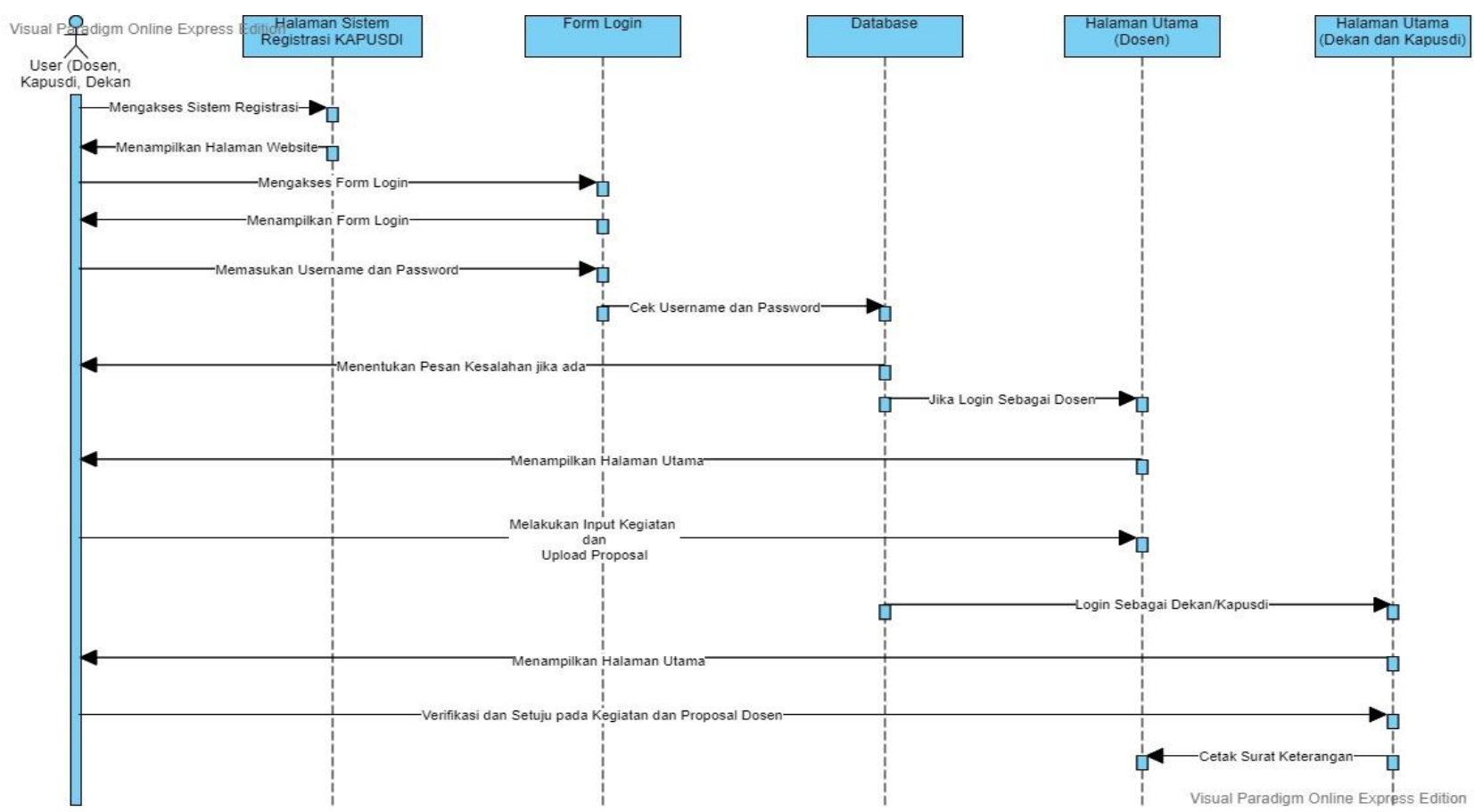

Gambar 11. Sequence Diagram

\subsubsection{Class Diagram}

Pada Gambar 11. Class Diagram menjelaskan design dari class diagram perancangan dari database yang akan dibuat, dimana terdapat sebelas entitas yang memiliki relasi satu sama lain dan entitas tersebut masing-masing mempunyai primary key sebagai attribute unik/ciri khas dari entitas tersebut.

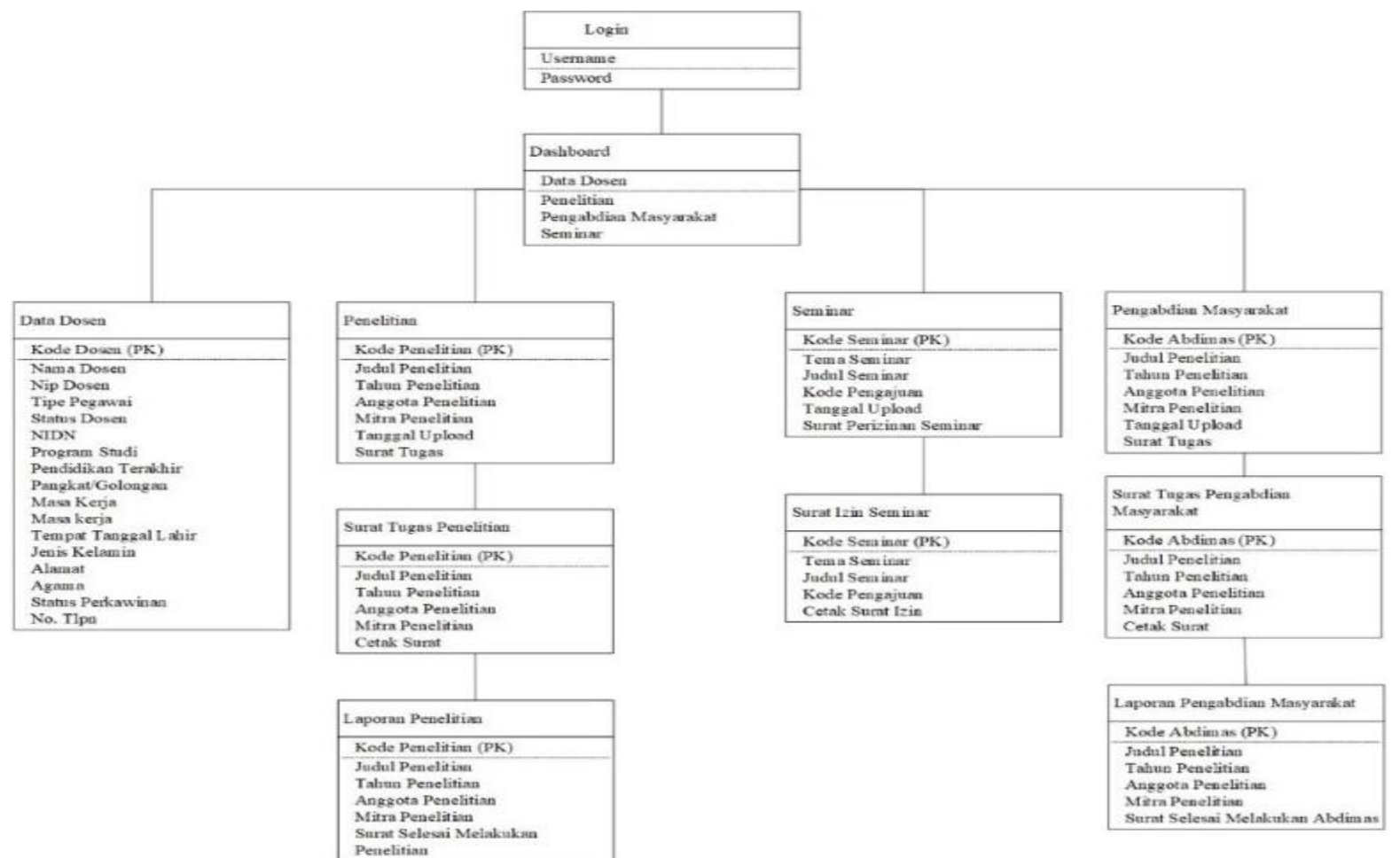

Gambar 11. Class Diagram 


\subsection{Perancangan User Interface}

Pada bagian ini akan membahas mengenai User Interface dari pengembangan sistem informasi pusat studi.

\subsubsection{Login Page}

Pada Gambar 13, menggambarkan ilustrasi rancangan antar muka pada halaman Login website. Halaman ini merupakan halaman dimana User diwajibkan memasukan email dan password agar bisa masuk ke website

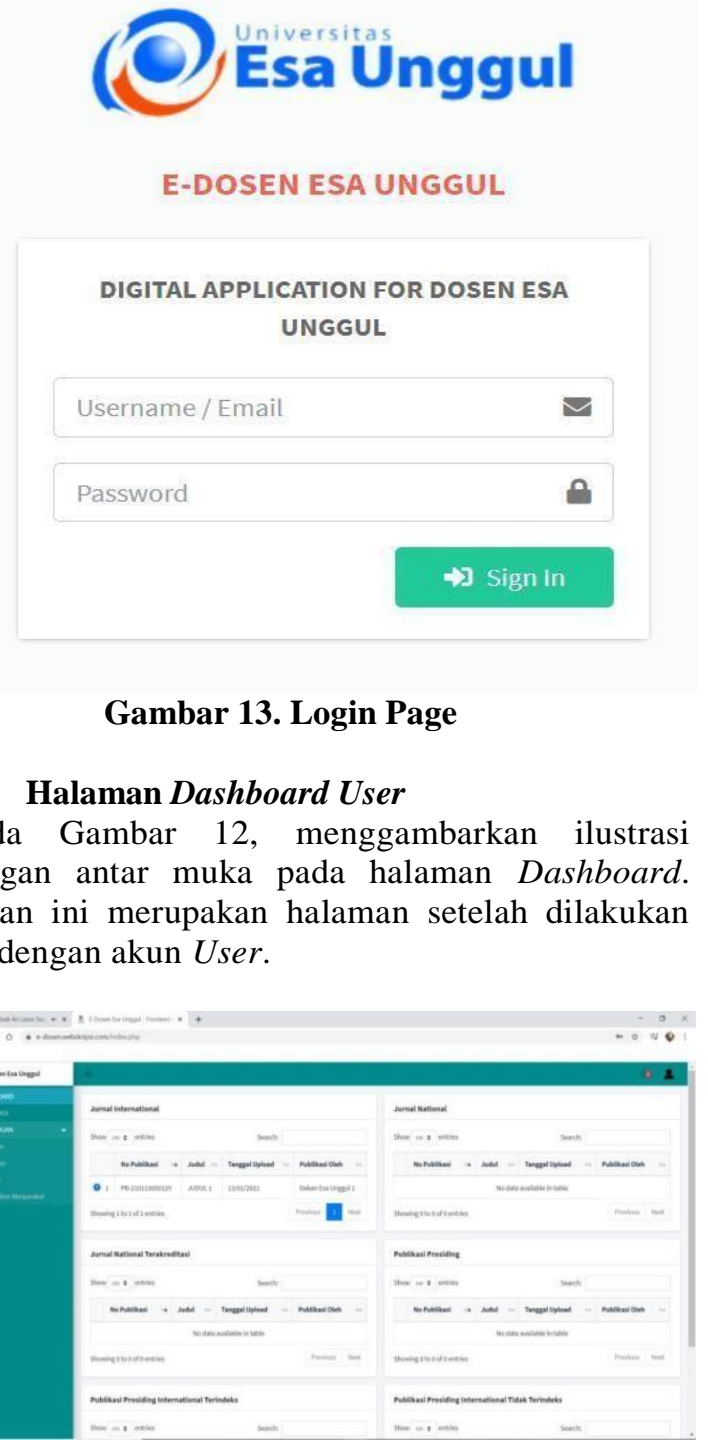

Gambar 12. Halaman Dashboard User

\subsubsection{Halaman Pengajuan Penelitian}

Pada Gambar 15. User Interface Penelitian mengilustrasikan kegiatan Dosen saat mengajukan rencana penelitian, selanjutnya Dosen memasukan data penelitian (Judul penelitian, nama dosen, anggota dosen), kemudian mengunggah proposal rencana penelitian.

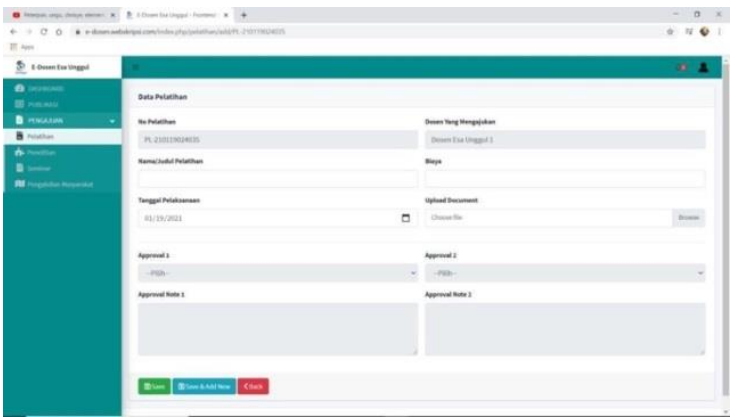

Gambar 15. User Interface Penelitian

\subsubsection{Halaman Pengajuan Pengabdian Masyarakat}

Pada Gambar 16. Wireframe Pengabdian Masyarakat mengilustrasikan kegiatan Dosen saat mengajukan rencana pengabdian masyarakat, selanjutnya Dosen memasukan data pengabdian masyarakat (Judul abdimas, nama dosen, anggota dosen), kemudian mengunggah proposal rencana pengabdian masyarakat.

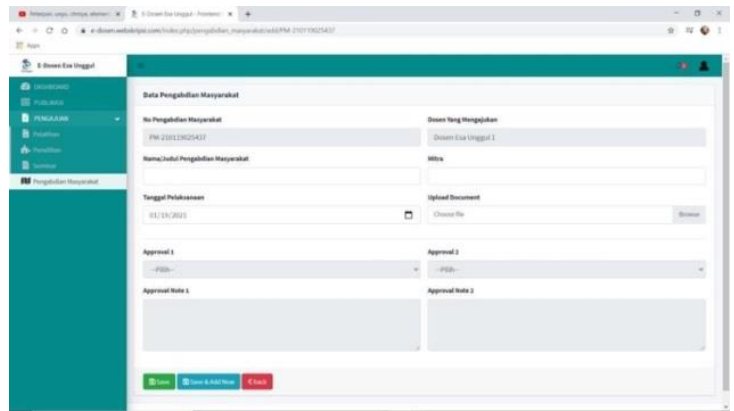

Gambar 16. User Interface Pengabdian Masyarakat

\subsubsection{Halaman Pengajuan Pelatihan}

Pada Gambar 17. User Interface Pengajuan Pelatihan mengilustrasikan kegiatan Dosen saat mengajukan rencana mengikuti pelatihan, selanjutnya Dosen memasukan data pelatihan yang akan diikuti, kemudian mengunggah undangan atau brosur pelatihan. 


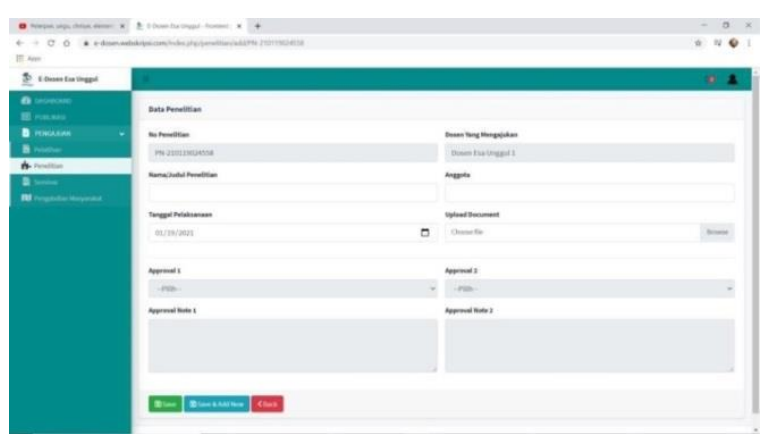

Gambar 17. User Interface Pengajuan Pelatihan

\subsubsection{Halaman Pengajuan Publikasi}

Pada Gambar 18. User Interface Pengajuan Publikasi menggambarkan proses pengajuan publikasi hasil penelitian atau pengabdian masyarakat yang akan di publikasi di jurnal ataupun prosiding nasional dan internasional.

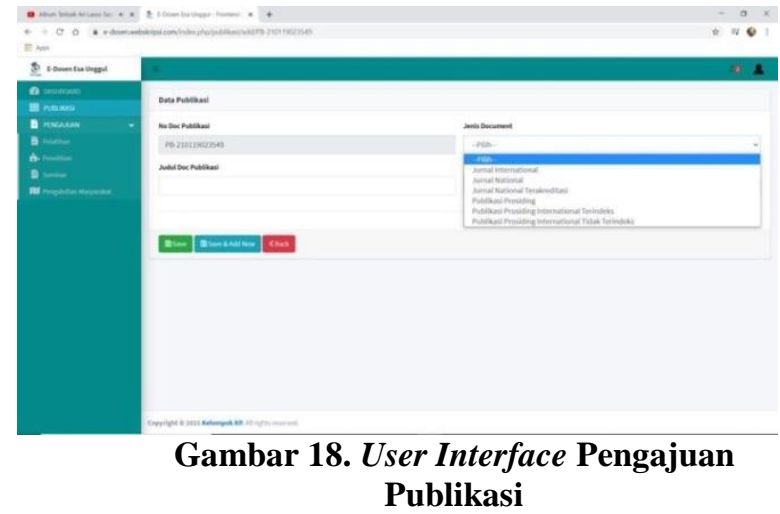

\subsubsection{Halaman Pengajuan Seminar}

Pada Gambar 19. User Interface Pengajuan Seminar menggambarkan proses pengajuan oleh Dosen untuk mengikuti seminar.

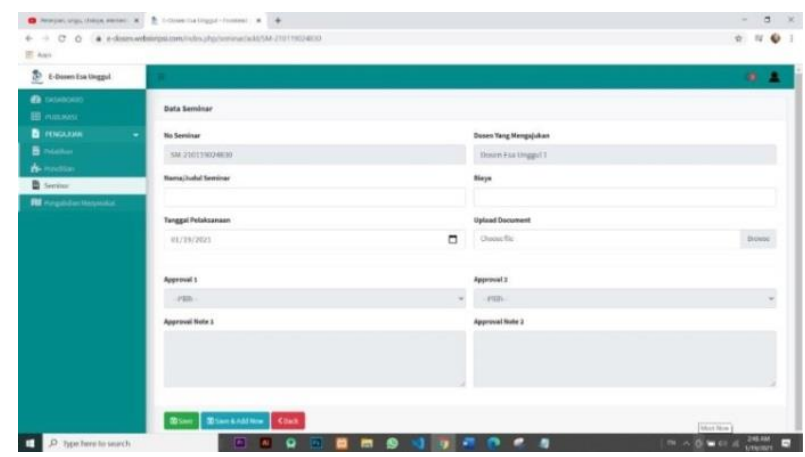

Gambar 19. User Interface Pengajuan Seminar

\subsubsection{Notifikasi}

Pada Gambar 20. Notifikasi menjelaskan bahwa Fitur Notifikasi ini akan keluar pada saat melakukan login pertama kali. Fitur ini memberikan keterangan kepada Kepala Pusat Studi dan Dekan jika ada pengajuan rencana dari Dosen. Dan di sisi Dosen akan memberikan informasi apakah pengajuan sudah di verifikasi atau belum.

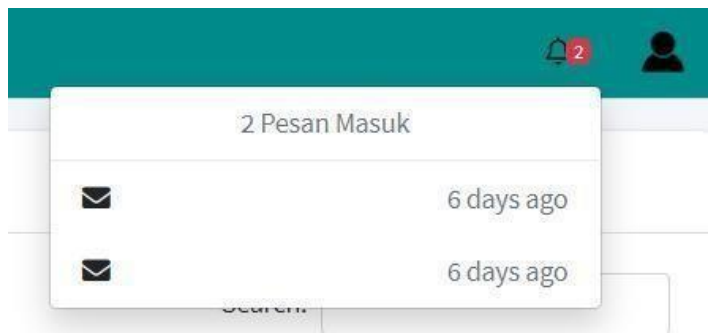

Gambar 20. Notifikasi

\section{KESIMPULAN}

Hasil analisis dan perancangan Sistem Informasi Pusat Studi diharapkan dapat membantu bagian dari kegiatan Tridharma Dosen. Dari hasil rancangan yang dibuat sudah dijelaskan secara rinci mengenai peran dari Dosen, Dekan dan Kepala Pusat studi terhadap masingmasing kegiatan yaitu Penelitian, Pengabdian Masyarakat, Pelatihan dan Publikasi/Seminar. Selanjutnya dapat membantu mempermudah kegiatan yang ingin dilakukan dosen serta repository kegiatan dosen yang dibutuhkan oleh Fakultas.

Penelitian ini menjadi landasan untuk penelitian selanjutnya dalam pengembangan sistem informasi pusat studi dan penilaian efektifitas penggunaan sistem tersebut dalam mendukung kegiatan tridarma dosen di Fakultas Ilmu Komputer Universitas Esa Unggul.

\section{SARAN}

Selain kesimpulan ada beberapa saran dalam melakukan perancangan pengembangan sistem ini. Implementasi system dilakukan dengan metode agile dan incremental, dimana system dibuat prototipe nya terlebih dahulu dan setiap cycle perlu di validasi efektifitas dan nilai tepat guna dari sistem tersebut. Selanjutnya untuk menghindari adanya kesalahan atau bug dalam implementasi system, maka pada setiap pengembangan system perlu dilakukan User Acceptance Test (Sandfreni \& Adikara, 2020), yang mana skenario testing harus dibuat oleh tim terpisah dengan pengembang sistem tersebut.

\section{DAFTAR PUSTAKA}

Adikara, F., \& Sandfreni, S. 2020. Combining Organization Goal-Oriented Elicitation and Wireframe for Fishery Product Sales Mobile Application Design. https://doi.org/10.4108/eai.2311-2019.2301492

Alvin, C., Peterson, B., \& Mukhopadhyay, S. 2021. Static generation of UML sequence diagrams. International Journal on Software Tools for Technology Transfer, 23(1). https://doi.org/10.1007/s10009-019-00545-z

Hendini, A. 2016. Pemodelan UML Sistem Informasi Monitoring Penjualan dan Stok Barang (Studi Kasus: Distro Zhezha Pontianak. Jurnal 
khatulistiwa informatika, VOL. IV, NO. 2 Desember 2016 Pemodelan. Crop Science, 23(2).

Hutahaean, J. 2017. Konsep Sistem Informasi. Jurnal Administrasi Pendidikan Informasi. Jurnal Administrasi Pendidikan.

Irmayani, W., \& Susyatih, E. 2017. Sistem Informasi Anggaran Pendapatan dan Belanja Desa Berorientasi Objek. Khatulistiwa Informatika, $V(1)$.

Ismanto, I., Hidayah, F., \& Kristinanti, K. (2020). Pemodelan Proses Bisnis Sistem Akademik Menggunakan Pendekatan Business Process Modelling Notation (BPMN). Jurnal Informasi, $7(2)$.

Lestari, S. 2018. Peran Teknologi dalam Pendidikan di Era Globalisasi. EDURELIGIA; JURNAL PENDIDIKAN AGAMA ISLAM, 2(2). https://doi.org/10.33650/edureligia.v2i2.459

Lipursari, A. 2019. Peran Sistem Informasi Manajemen (Sim) Dalam Pengambilan Keputusan. JURNAL STIE SEMARANG, 53(9).

Munawar. 2018. Analisis Perancangan Sistem Berorientasikan Objek dengan UML (Unified Modeling Language). In Bandung: Informatika.

OMG. 2021. Object Management Group Business Process Model and Notation BPMN. Object Management Group, Inc.

Rizky Muhammad; Irma Kartika Wairooy, S.Kom., M. T. 2019. UML Diagram: Activity Diagram. In Https://Socs.Binus.Ac.Id/.

Sandfreni,Adikara, F., Anggarani, A., \& Others. 2018. Qualitative Requirements Analysis Process in Organization Goal-Oriented Requirements Engineering (OGORE) for E-Commerce Development. In IT Convergence and Security 2017 (pp. 318-324). Springer.

Sandfreni,Surendro, I. K. 2016. Requirements
Engineering Model: Role Based Goal Oriented Model. MATEC Web of Conferences, 52, 1004.

Sandfreni, S., \& Adikara, F. 2019. Menyelaraskan Perencanaan Strategi Teknologi Informasi yang Didasarkan pada Strategi Manajamen Teknologi Informasi dan Strategi Bisnis. Computatio: Journal of Computer Science and Information Systems, $3(1)$. https://doi.org/10.24912/computatio.v3i1.2723

Sandfreni, S., \& Adikara, F. 2020. The Implementation of Soft System Methodology (SSM) for Systems Development in Organizations (Study Case: The Development of Tourism Information System in Palembang City). https://doi.org/10.4108/eai.2311-2019.2301495

Setiawan, H., \& Khairuzzaman, M. Q. 2017. Perancangan Sistem Informasi Manajemen Proyek: Sistem Informasi Kontraktor. Perancangan Sistem Informasi Manajemen Proyek: Sistem Informasi Kontraktor, V(2).

Sukamto, R. A., \& Shalahuddin, M. 2016. Rekayasa Perangkat Lunak (Terstruktur dan berbasis objek). In Sdlc (Vol. 4).

Sunarto, S. 2015. Analisa Kebijakan PAI di Indonesia (Dampak UU Nomor 14 Tahun 2005 Tentang Guru dan Dosen Bagi Guru Madrasah). Al-Tadzkiyyah: Jurnal Pendidikan Islam, 6(1).

Triandini, E., Jayanatha, S., Indrawan, A., Werla Putra, G., \& Iswara, B. 2019. Metode Systematic Literature Review untuk Identifikasi Platform dan Metode Pengembangan Sistem Informasi di Indonesia. Indonesian Journal of Information Systems, l(2). https://doi.org/10.24002/ijis.v1i2.1916

Yunaeti Anggraeni, E. 2017. Pengantar Sistem Informasi. Igarss 2017, 150(1). 